Prepared in cooperation with the Kansas Water Office

\title{
Suspended-Sediment Loads and Reservoir Sediment Trap Efficiency for Clinton Lake, Kansas, 2010-12
}

Scientific lavestigations Report $2013-5153$

U.S. Department of the Interiof U.S. Geological Survey 
Cover. Clinton Lake (photograph by Kyle Juracek, U.S. Geological Survey). 


\section{Suspended-Sediment Loads and Reservoir Sediment Trap Efficiency for Clinton Lake, Kansas, 2010-12}

By Kyle E. Juracek

Prepared in cooperation with the Kansas Water Office

Scientific Investigations Report 2013-5153 


\title{
U.S. Department of the Interior SALLY JEWELL, Secretary
}

\section{U.S. Geological Survey Suzette M. Kimball, Acting Director}

\author{
U.S. Geological Survey, Reston, Virginia: 2013
}

For more information on the USGS - the Federal source for science about the Earth, its natural and living resources, natural hazards, and the environment, visit http://www.usgs.gov or call 1-888-ASK-USGS.

For an overview of USGS information products, including maps, imagery, and publications, visit http://www.usgs.gov/pubprod

To order this and other USGS information products, visit http://store.usgs.gov

Any use of trade, firm, or product names is for descriptive purposes only and does not imply endorsement by the U.S. Government.

Although this information product, for the most part, is in the public domain, it also may contain copyrighted materials as noted in the text. Permission to reproduce copyrighted items must be secured from the copyright owner.

Suggested citation:

Juracek, K.E., 2013, Suspended-sediment loads and reservoir sediment trap efficiency for Clinton Lake, Kansas, 2010-12: U.S. Geological Survey Scientific Investigations Report 2013-5153, 10 p., http://pubs.usgs.gov/ sir/2013/5153/. 


\section{Acknowledgments}

This study was made possible, in part, by support from the Kansas Water Office and the Kansas State Water Plan Fund. The author gratefully acknowledges Chris Gnau (Kansas Water Office) for providing a technical review of the report.

Several U.S. Geological Survey individuals also are recognized for their invaluable assistance in the completion of this study. For operation and maintenance of water-quality monitors, completion of water-quality records, and collection of suspended-sediment samples, the author gratefully acknowledges the following individuals: Trudy Bennett, Patrick Finnegan, Guy Foster, Jackline Gatotho, Bill Holladay, Brian Klager, Eric Looper, Ben Prewitt, Deneise Schneider, and Andrew Toth. For the completion of multiple discharge measurements near the Clinton Lake outlet, Guy Foster is acknowledged with appreciation. For assistance with database development, the author gratefully acknowledges Brian Klager. Finally, for providing a technical review of the report, the author gratefully acknowledges Guy Foster and David Heimann. 


\section{Contents}

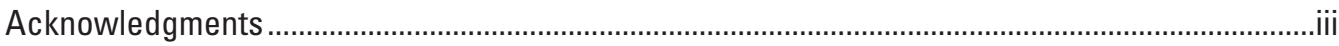

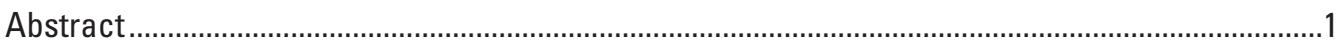

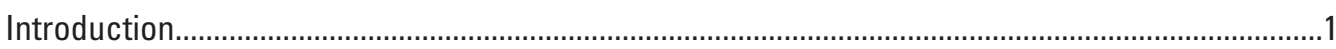

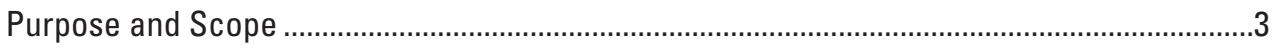

Description of Clinton Lake Basin .........................................................................................

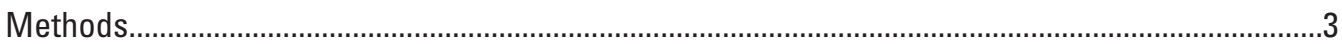

Continuous Streamflow and Water-Quality Monitoring .........................................................

Suspended-Sediment Sample Collection and Analysis ...............................................................

Quality Assurance .................................................................................................................

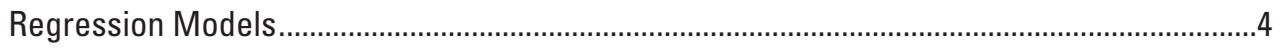

Computation of Sediment Concentrations, Loads, and Yield..................................................

Estimation of Reservoir Sediment Trap Efficiency ………................................................

Characterization of Sediment Loading To and From Clinton Lake ..................................................

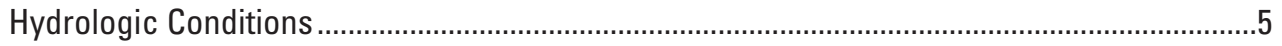

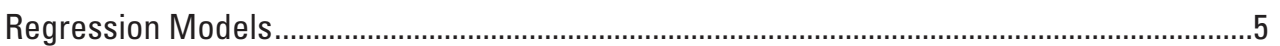

Sediment Loads, Yield, and Reservoir Sediment Trap Efficiency ..........................................

Stormflow Effects on Sediment Transport.........................................................................

Sediment Sources for Clinton Lake ..........................................................................................

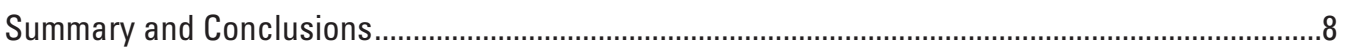

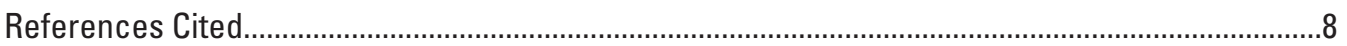

\section{Figures}

1. Map showing the location of Clinton Lake Basin, Clinton Lake, selected U.S. Geological Survey streamgage, and land use in the Clinton Lake Basin, northeast Kansas.

2. Graph showing relation between cross-sectional median and in-stream turbidity measurements for the Wakarusa River near Richland streamgage upstream from Clinton Lake, 2011-12

3. Graph showing variation in annual mean discharge at the Wakarusa River near Richland streamgage, 2004-12.

4. Graphs showing regression models used to compute suspended-sediment concentration based on turbidity at the Wakarusa River near Richland streamgage and the Clinton Lake outlet site, water years 2011 and 2012 


\section{Tables}

1. Suspended-sediment concentrations for original and duplicate suspendedsediment samples collected at the Richland streamgage upstream from Clinton Lake, 2011-12 ...................................................................................................

2. Regression models used for computing suspended-sediment concentrations and loads

3. Suspended-sediment concentration, in-stream turbidity, discharge, percent silt/clay, and particle-size distribution from discrete samples collected at the Wakarusa River near Richland streamgage and the Clinton Lake outlet site, 2011-12.

\section{Conversion Factors and Abbreviations}

\begin{tabular}{|c|c|c|}
\hline Multiply & By & To obtain \\
\hline \multicolumn{3}{|c|}{ Length } \\
\hline inch (in.) & 2.54 & centimeter $(\mathrm{cm})$ \\
\hline inch (in.) & 25.4 & millimeter (mm) \\
\hline foot (ft) & 0.3048 & meter (m) \\
\hline mile (mi) & 1.609 & kilometer (km) \\
\hline \multicolumn{3}{|c|}{ Area } \\
\hline square mile $\left(\mathrm{mi}^{2}\right)$ & 259.0 & hectare (ha) \\
\hline square mile $\left(\mathrm{mi}^{2}\right)$ & 2.590 & square kilometer $\left(\mathrm{km}^{2}\right)$ \\
\hline \multicolumn{3}{|c|}{ Volume } \\
\hline cubic foot $\left(\mathrm{ft}^{3}\right)$ & 0.02832 & cubic meter $\left(\mathrm{m}^{3}\right)$ \\
\hline cubic foot $\left(\mathrm{ft}^{3}\right)$ & 0.00002296 & acre-foot (acre-ft) \\
\hline acre-foot (acre-ft) & 1,233 & cubic meter $\left(\mathrm{m}^{3}\right)$ \\
\hline \multicolumn{3}{|c|}{ Flow rate } \\
\hline cubic foot per second $\left(\mathrm{ft}^{3} / \mathrm{s}\right)$ & 0.02832 & cubic meter per second $\left(\mathrm{m}^{3} / \mathrm{s}\right)$ \\
\hline \multicolumn{3}{|c|}{ Mass } \\
\hline pound (lb) & 0.4536 & kilogram (kg) \\
\hline ton & 2,000 & pound (lb) \\
\hline ton & 0.9072 & megagram $(\mathrm{Mg})$ \\
\hline ton per day (ton/d) & 0.9072 & metric ton per day \\
\hline ton per year (ton/yr) & 0.9072 & metric ton per year \\
\hline
\end{tabular}





\title{
Suspended-Sediment Loads and Reservoir Sediment Trap Efficiency for Clinton Lake, Kansas, 2010-12
}

\author{
By Kyle E. Juracek
}

\begin{abstract}
Continuous streamflow and turbidity data collected from October 1, 2010, to September 30, 2012, at a site upstream and downstream from Clinton Lake, Kansas, were used to compute the total suspended-sediment load delivered to and released from the reservoir as well as the sediment trap efficiency for the reservoir. Ongoing sedimentation is inhibiting the ability of Clinton Lake to serve several purposes including flood control, water supply, and recreation.

The inflow suspended-sediment load was substantially larger than the outflow load and most of the suspended-sediment load was delivered during short-term, high-discharge periods. Respectively, the total 2-year inflow and outflow suspended-sediment loads were computed to be 44.4 and 1.49 million pounds. Sediment trap efficiency for the reservoir was estimated to be 97 percent. The mean annual suspendedsediment yield from the upstream basin was estimated to be 60,500 pounds per square mile. Because this study was completed during a drought, the estimated inflow suspended-sediment load and suspended-sediment yield likely are substantially less than what would occur during a period of average or above average precipitation and runoff.
\end{abstract}

\section{Introduction}

The continual loss of reservoir water-storage capacity caused by ongoing sedimentation is an increasing concern in Kansas and nationally because reservoirs serve various important purposes. Clinton Lake is a Federal impoundment on the Wakarusa River in Douglas County, northeast Kansas (fig. 1). The reservoir officially was completed in 1977 by the U.S. Army Corps of Engineers (USACE) with an original design life of 100 years (U.S. Army Corps of Engineers, 1979). The reservoir is used for several purposes including flood control, water supply, recreation, water-quality control, and fish and wildlife (Susanna Gehrt, U.S. Army Corps of Engineers, written commun., 2010).

In 1977, Clinton Lake had an original surface area of about 7,010 acres and a water-storage capacity of about 129,200 acre-feet (acre-ft) at the conservation (multi-purpose) pool elevation of 875.5 feet ( $\mathrm{ft}$ ) above the National Geodetic Vertical Datum of 1929 (NGVD29) (U.S. Army Corps of Engineers, 1979). Based on a bathymetric survey completed in 2009 by the Kansas Biological Survey, water-storage capacity at the conservation-pool elevation was about 119,100 acre-ft (Kansas Biological Survey, 2010). The decrease in storage capacity is the result of ongoing sedimentation. As of 2012, the reservoir had lost an estimated 8.6 percent of its conservation-pool storage capacity. The estimated sedimentation rate of 337 acre-ft per year is about 80 percent larger than the sedimentation rate (190 acre-ft per year) that originally was projected for the conservation pool by USACE at the time the reservoir was completed (Kansas Water Office, 2012). Thus, the reservoir is filling with sediment faster than originally anticipated. As sedimentation continues, the ability of Clinton Lake to serve its various purposes will decline. Presently (2012), 81 percent of the conservation-pool storage is watersupply storage (Nathan Westrup, Kansas Water Office, oral commun., 2012).

The development of a sediment management plan to extend the projected life of Clinton Lake requires an understanding of the amount of sediment delivered to, retained in, and released from the reservoir. To provide some of the required information, a 3-year study by the U.S. Geological Survey (USGS), in cooperation with the Kansas Water Office, was begun in 2010. Specific objectives of the study were to:

1. Compute the suspended-sediment loads delivered to and released from Clinton Lake; and

2. Estimate the suspended-sediment trap efficiency for Clinton Lake.

An emphasis on suspended sediment is appropriate because most of the deposited sediment in large reservoirs typically is silt and clay (Morris and Fan, 1998; Owens and others, 2005). In a recent study of Clinton Lake that included an analysis of multiple bottom-sediment cores, Juracek (2011a) determined that the silt and clay content of the sediment typically was equal to or greater than 99 percent. 


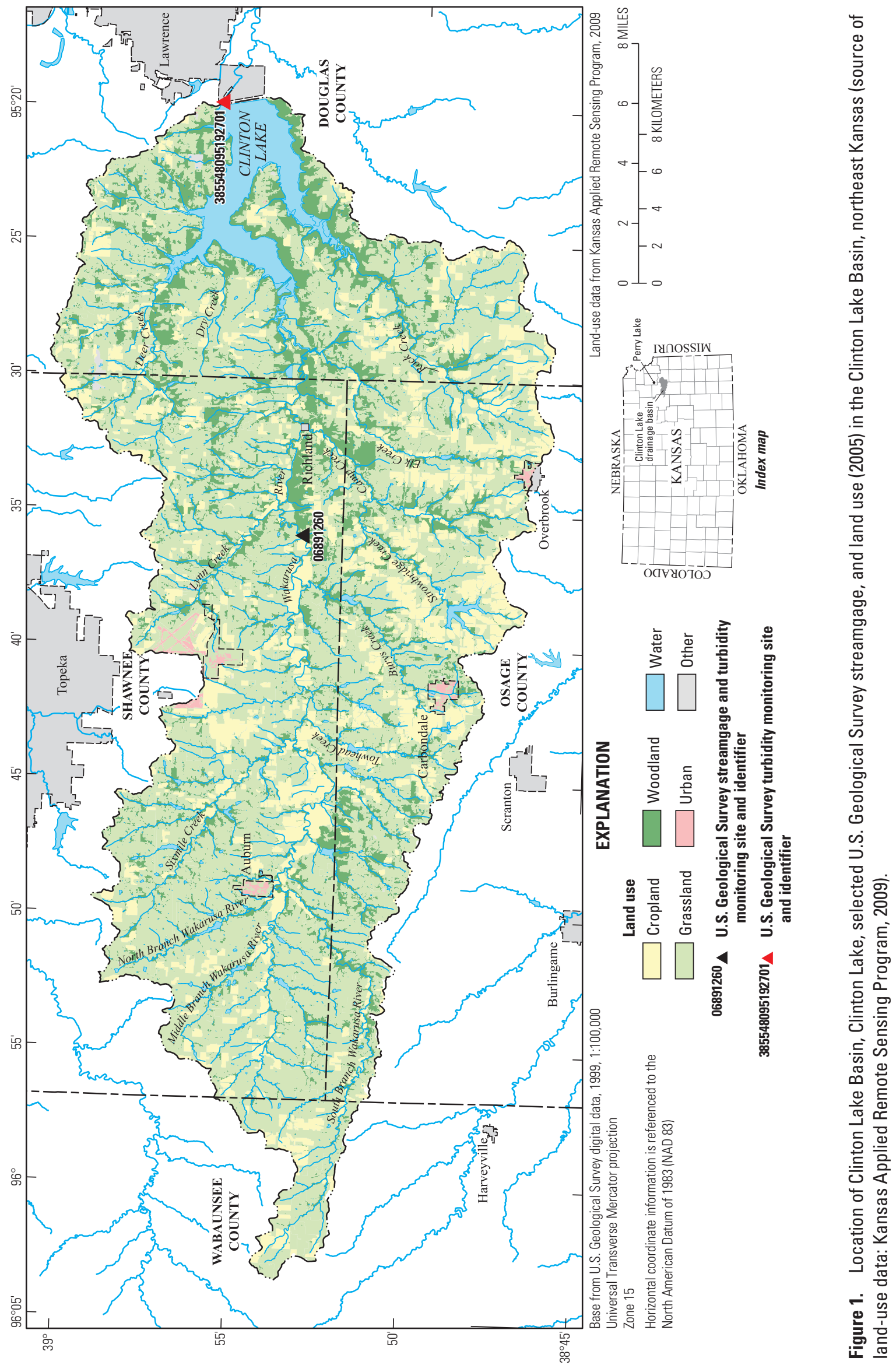




\section{Purpose and Scope}

The purpose of this report is to present the results of the USGS study to compute suspended-sediment loads delivered to and released from Clinton Lake, and to estimate the suspended-sediment trap efficiency of the reservoir, from October 1,2010 , to September 30,2012. Study objectives were met by the collection of continuous streamflow and turbidity data at an inflow and outflow site for the reservoir and the collection of discrete water samples at the inflow and outflow sites that were analyzed for suspended-sediment concentration. Results presented in this report will assist the Kansas Water Office in efforts to evaluate sediment management options for the reservoir and its upstream basin. From a national perspective, the methods and results presented in this report will provide guidance and perspective for future reservoir studies concerned with sediment management issues.

\section{Description of Clinton Lake Basin}

The Clinton Lake Basin is an area of about 367 square miles $\left(\mathrm{mi}^{2}\right)$ located in northeast Kansas (fig. 1). Most of the Clinton Lake Basin is located in the Dissected Till Plains section of the Central Lowland physiographic province (Fenneman, 1946; Schoewe, 1949). This section is characterized by dissected deposits of glacial till that consist of clay, silt, sand, gravel, and boulders. The underlying bedrock primarily is limestone and shale (with some sandstone) of Pennsylvanian age (Schoewe, 1949; Jordan and Stamer, 1995). Soils in the basin are erodible and mostly are clay loam, silt loam, and silty clay loam. Slopes in the basin range from nearly level to gently sloping on the flood plains and from gently sloping to steep in the uplands. Generally, slopes are less than 10 percent but locally may be as steep as 25 percent (U.S. Department of Agriculture, Soil Conservation Service, 1970, 1977, 1985, 1991). In addition to the Wakarusa River, several small tributaries contribute flow directly to Clinton Lake (fig. 1).

Long-term mean annual precipitation at Auburn, Kansas, located in the upstream part of the Clinton Lake Basin (fig. 1), was about 36 inches (period of record 1960-2011) (High Plains Regional Climate Center, 2012). Most of the annual precipitation is received during the growing season (generally April-September).

Land use (2005) in the Clinton Lake Basin mostly is agricultural with grassland and cropland accounting for about 59 and 17 percent of the basin, respectively. Woodland accounts for about 18 percent of the basin. Urban land use occupies about 1 percent of the basin (fig. 1) (Kansas Applied Remote Sensing Program, 2009).

\section{Methods}

The objectives of the study were accomplished using newly collected and available information. For the purposes of estimating suspended-sediment loads and reservoir sediment trap efficiency, continuous streamflow and turbidity data and suspended-sediment samples were collected at a USGS streamgage site located upstream from Clinton Lake. Continuous turbidity data and suspended-sediment samples also were collected downstream from Clinton Lake near the outlet. Turbidity has been shown to be a frequently reliable predictor of suspended-sediment concentration (Rasmussen and others, 2009). Streamflow data for the outlet site were assembled using gate-change information provided by USACE.

\section{Continuous Streamflow and Water-Quality Monitoring}

Continuous inflow data for Clinton Lake were collected at the Wakarusa River near Richland (hereafter Richland) streamgage (station 06891260, fig. 1) as part of the USGS national streamgaging network using standard USGS methods (Turnipseed and Sauer, 2010). The Richland streamgage monitors the inflow from about 45 percent of the basin upstream from the reservoir. For this study, hourly streamflow data for October 1, 2010, through September 30, 2011, (water year 2011) and October 1, 2011, through September 30, 2012, (water year 2012) were used (U.S. Geological Survey, 2013). Hourly outflow data for Clinton Lake were assembled using gate-change information provided by USACE (Susanna Gehrt, U.S. Army Corps of Engineers, written commun., 2012) that was revised on the basis of multiple streamflow measurements made during various reservoir releases.

Continuous hourly turbidity data also were collected during the 2011 and 2012 water years at the Richland and outlet sites. For this purpose, a YSI monitor (model 6600 or 600 OMS) with an optical turbidity sensor (model 6136) was used. The YSI 6136 turbidity sensor can measure turbidity over a published range of 0 to 1,000 formazin nephelometric units (FNUs) (YSI, 2007). At both sites, the YSI monitor was housed in an open-ended polyvinyl chloride (PVC) pipe drilled with holes to allow stream water to flow through the installation. At Richland, the monitor was suspended from a bridge by chain in the main flow zone of the river. At the outlet site, located within the channelized and riprapped section of channel, the monitor was installed along the river bank about $700 \mathrm{ft}$ downstream from the reservoir outflow structure.

YSI turbidity time-series data sometimes were missing or deleted from the continuous record because of equipment malfunctions or sensor fouling. To provide a complete hourly turbidity data set, data for these brief periods (that is, typically one or a few hours) were estimated by interpolation (Rasmussen and Ziegler, 2003; Rasmussen and others, 2005).

At each site, the sensors were cleaned and calibrated approximately every 3 months. Additional cleaning visits were 
made when real-time data indicated errors caused by environmental fouling. Quality-assurance checks were made before and after sensor cleaning and calibration using an independently calibrated sensor. Sensor cleaning and calibration were done in accordance with guidance provided by Wagner and others (2006).

\section{Suspended-Sediment Sample Collection and Analysis}

Suspended-sediment samples were collected at the Richland and outlet monitoring sites for Clinton Lake (fig. 1) using equal-width increment methods as described in Nolan and others (2005). At the Richland site, a total of 9 samples were collected that provide data for a range of streamflow and turbidity conditions. At the outlet site, a total of 6 samples were collected that provide data for a range of reservoir releases and turbidity conditions. All samples were analyzed for suspendedsediment concentration (SSC). Selected samples also were analyzed for particle-size distribution [percent of suspended sediment (by weight) less than 100, 63, 31, 16, 8, 4, and 2 micrometers $(\mu \mathrm{m})$ in diameter]. All SSC and particle-size analyses were completed at the USGS Sediment Laboratory in Iowa City, Iowa, using methods described by Guy (1969).

\section{Quality Assurance}

Quality assurance was provided by evaluations of variability for turbidity measurements and SSC analyses. During the collection of suspended-sediment samples, turbidity was measured across the width of the stream. Median turbidity values of the cross-sectional measurements were compared with the in-stream (fixed location) sensor at each site to assess the ability of the in-stream sensor to provide turbidity data that were representative across the width of the stream. As part of each comparison, the coefficient of determination $\left(R^{2}\right)$ was computed. The $R^{2}$ is the fraction of the variance explained by a regression model (Helsel and Hirsch, 1992). It provides an indication of the goodness of fit of a model (that is, its ability to accurately model a data set). The larger the $R^{2}$ (up to a maximum possible value of 1.0), the more reliable is the model. Comparisons indicated that the in-stream sensors generally

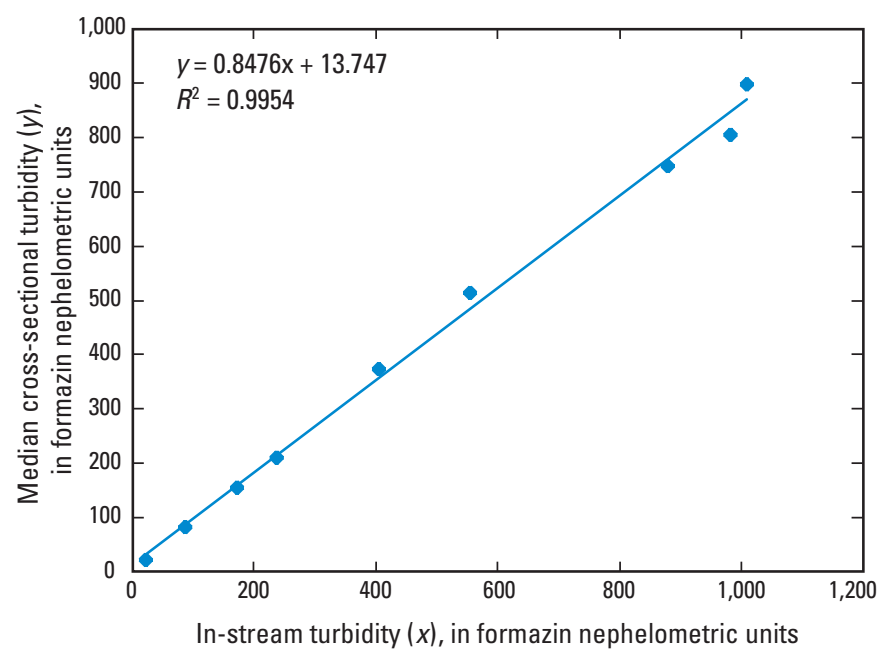

Figure 2. Relation between cross-sectional median and in-stream (fixed location) turbidity measurements for the Wakarusa River near Richland streamgage (station 06891260) upstream from Clinton Lake, 2011-12. $R^{2}$ is the coefficient of determination.

provided turbidity data that were representative of conditions across the width of the Wakarusa River. For example, the relation between the cross-sectional median and in-stream (fixed location) turbidity measurements for the Richland site is shown in figure 2 .

To assess variability in the SSC analyses, duplicate suspended-sediment samples were collected and analyzed for SSC. For two duplicate samples collected at the Richland site, SSC values were within 1 percent of the original samples (table 1).

\section{Regression Models}

Ordinary-least-squares regression analysis was used to develop statistical relations between in-stream turbidity and SSC. The regression models, used for the purpose of computing hourly SSC and suspended-sediment load (SSL), were developed in accordance with procedures described by Rasmussen and others (2009). All data were log-transformed to better approximate normality and to even the variability in

Table 1. Suspended-sediment concentrations for original and duplicate suspended-sediment samples collected at the Richland streamgage (station 06891260) upstream from Clinton Lake, 2011-12.

[Results for duplicate samples are listed parenthetically. $\mathrm{ft}^{3} / \mathrm{s}$, cubic feet per second; FNU, formazin nephelometric units; mg/L, milligrams per liter]

\begin{tabular}{|c|c|c|c|c|}
\hline $\begin{array}{c}\text { Date of sample collection } \\
\text { (month/day/year) }\end{array}$ & Discharge $\left(\mathrm{ft}^{3} / \mathrm{s}\right)$ & Turbidity ${ }^{1}$ (FNU) & $\begin{array}{l}\text { Suspended-sediment } \\
\text { concentration (mg/L) }\end{array}$ & $\begin{array}{l}\text { Percentage difference } \\
\text { between duplicate and } \\
\text { original sample }\end{array}$ \\
\hline $05 / 26 / 11$ & 737 & 555 & $770(764)$ & -0.8 \\
\hline
\end{tabular}

${ }^{1}$ Turbidity measured by in-stream (fixed location) YSI model 6136 turbidity sensor. 
regression residuals. After development and application of the regression models, SSC and SSL values were retransformed back to linear space. Because retransformation can introduce bias, a bias correction factor (Duan's smearing estimator; Duan, 1983) was used as a multiplier to correct the retransformed SSC and SSL values (Helsel and Hirsch, 1992).

The use of turbidity data in a regression model can provide more reliable and reproducible estimates of SSC and SSL than a regression model that uses discharge as the sole independent variable (Rasmussen and others, 2009). Use of discharge only to estimate SSC and SSL may result in overprediction (Lee and others, 2008; Juracek, 2011b).

Development of the regression models to compute SSC using in-stream turbidity required that each suspendedsediment sample had an associated turbidity value. For each sample, the average YSI 6136 turbidity during the time of sample collection was used.

\section{Computation of Sediment Concentrations, Loads, and Yield}

Instantaneous SSC was computed for each hour of the 2-year period of record using regression models developed for the relation between in-stream YSI 6136 turbidity and SSC for the Richland and outlet sites. Instantaneous SSL was calculated using the following equation:

$$
S S L_{i}=S S C_{i} \times Q_{i} \times c,
$$

where

$$
\begin{aligned}
& S S L_{i} \quad \text { is the computed instantaneous suspended- } \\
& S_{S S C} \text { is the computed instantaneous suspended- }
\end{aligned}
$$

Hourly SSL was computed for each hour of the 2-year period of record by multiplying the instantaneous SSL by 3,600.

The total SSL for each site was computed as the sum of the hourly SSL values for the 2-year period. The total inflow SSL for Clinton Lake was estimated as the total SSL computed for the Richland site multiplied by 1.55 to account for the 55 percent of the Clinton Lake Basin that was not monitored. Use of the multiplier required the assumption that the SSL originating from the unmonitored part of the basin was similar to the SSL originating from the monitored part of the basin on a per unit area basis. The assumption was considered reasonable given the generally consistent distribution of soil types and land use in the basin (Kansas Applied Remote Sensing Program, 2009; U.S. Department of Agriculture, Soil Conservation Service, 1970, 1977, 1985, 1991). Mean annual suspended-sediment yield for the Clinton Lake Basin was estimated as the total SSL for the 2-year period divided by two then divided by basin area.

\section{Estimation of Reservoir Sediment Trap Efficiency}

Reservoir sediment trap efficiency provides an indication of the proportion of the total inflow suspended-sediment load that is deposited and permanently stored within a reservoir. For this study, trap efficiency was estimated for Clinton Lake for the 2-year period that consisted of the 2011 and 2012 water years. Trap efficiency for the reservoir was estimated as the total deposited suspended-sediment load (computed as total inflow suspended-sediment load minus total outflow suspended-sediment load) divided by the total inflow suspendedsediment load and expressed as a percentage. The total inflow and outflow suspended-sediment loads for Clinton Lake were estimated using data collected at the Richland and outlet sites, respectively (fig. 1). Because the contribution of sediment from shoreline erosion was not accounted for, the estimated trap efficiency may be conservative (that is, lower than actual).

\section{Characterization of Sediment Loading To and From Clinton Lake}

\section{Hydrologic Conditions}

To provide an indication of how Clinton Lake inflows for water years 2011 and 2012 (that is, the 2-year study period) compared to historical conditions, the annual mean discharges for the period of record (2004 to 2012) were examined for the Richland site (station 06891260, fig. 1). Because there commonly is a direct relation between discharge and SSL (Morris and Fan, 1998), the variability in annual mean discharge also provides an indication of the year-to-year variability in SSL delivered to the reservoir. The annual mean discharge for water years 2011 and 2012 at the Richland site averaged $23 \mathrm{ft}^{3} / \mathrm{s}$, which was substantially less than the median annual discharge for the period of record of $120 \mathrm{ft}^{3} / \mathrm{s}$ (U.S. Geological Survey, 2013) (fig. 3). The 2-year study period was a time of drought in the Clinton Lake Basin (Mary Knapp, Kansas State University, written commun., 2013). Zero flow was measured at the Richland site for all or part of 16 and 95 days during water years 2011 and 2012, respectively. During water year 2012, zero flow was measured continuously from July 23 to September 30 .

\section{Regression Models}

Regression models were developed for the purpose of computing hourly SSC and SSL for the 2-year study period at 
the Richland and outlet sites (table 2, fig. 4). Each regression model was developed using a model calibration data set that consisted of discrete samples for which SSC, turbidity, and discharge were determined (table 3).

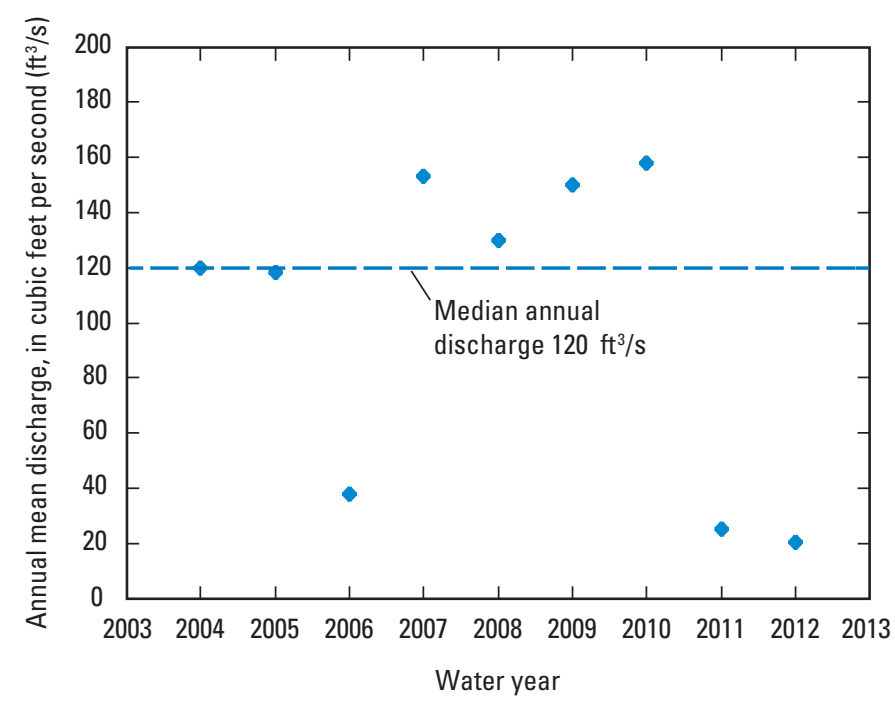

Figure 3. Variation in annual mean discharge at the Wakarusa River near Richland streamgage (station 06891260), 2004-12.

In addition to $\mathrm{SSC}$, the particle-size distribution (seven size classes) of the suspended sediment was determined for five of the nine samples collected at the Richland site (table 3 ). For all nine samples, the median percentage of silt and clay (particles less than $63 \mu \mathrm{m}$ in diameter) was 97 percent (table 3). Particle-size distribution analyses were not attempted for samples collected at the outlet site because of the small amount of suspended sediment in the samples.

\section{Sediment Loads, Yield, and Reservoir Sediment Trap Efficiency}

Total inflow SSL for Clinton Lake was computed for the monitored part of the basin and adjusted to account for the unmonitored part of the basin. The total 2-year inflow SSL to

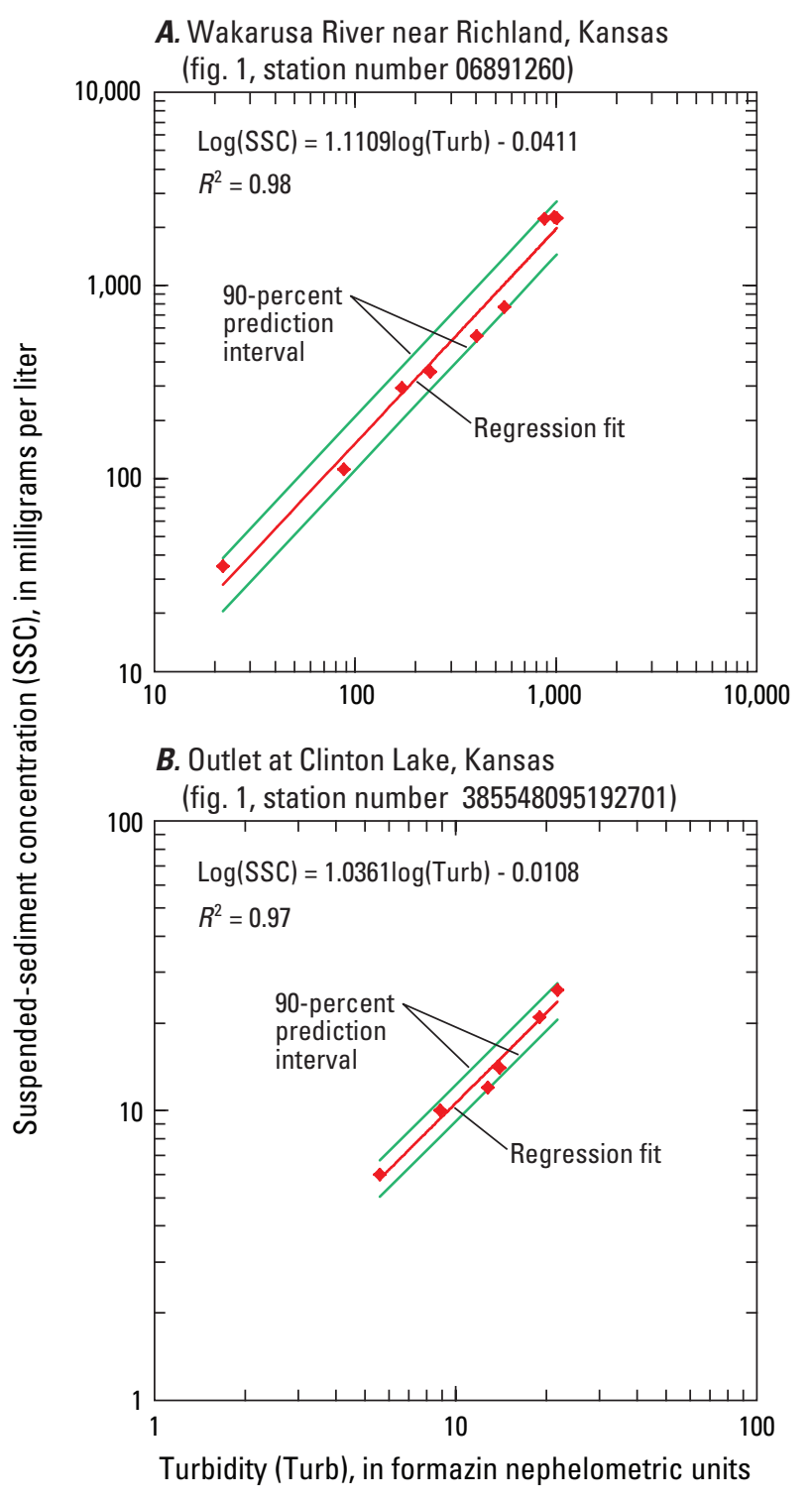

Figure 4. Regression models used to compute suspendedsediment concentration based on turbidity at $A$, the Wakarusa River near Richland streamgage (station 06891260) and $B$, the Clinton Lake outlet site, water years 2011 and 2012. $R^{2}$ is the coefficient of determination.

Table 2. Regression models used for computing suspended-sediment concentrations and loads.

$\left[R^{2}\right.$, coefficient of determination; MSPE, model standard percentage error; FNU, formazin nephelometric units; SSC, suspended-sediment concentration; $\mathrm{mg} / \mathrm{L}$, milligrams per liter; Turb, turbidity in formazin nephelometric units]

\begin{tabular}{lcccccc}
\hline Regression model & $\begin{array}{c}\text { Duan bias } \\
\text { correction }\end{array}$ & $\boldsymbol{R}^{\mathbf{2}}$ & $\begin{array}{c}\text { Mean MSPE2 } \\
\text { (in percent) }\end{array}$ & $\begin{array}{c}\text { Number of } \\
\text { samples }\end{array}$ & $\begin{array}{c}\text { Range in tur- } \\
\text { bidity (FNU) }\end{array}$ & $\begin{array}{c}\text { Range in SSC } \\
\text { (mg/L) }\end{array}$ \\
\hline & Wakarusa River near Richland, Kansas (fig. 1, station number 06891260) & \\
\hline $\log (\mathrm{SSC})=1.1109 \log (\mathrm{Turb})-0.0411$ & 1.02 & 0.98 & 23 & 9 & $22-1,010$ \\
\hline \multicolumn{8}{c}{ Outlet at Clinton Lake, Kansas (fig. 1, station number 385548095192701) } \\
\hline $\log (\mathrm{SSC})=1.0361 \log ($ Turb) -0.0108 & 1.00 & 0.97 & 9 & 6 & $5.6-21.8$ \\
\hline
\end{tabular}

${ }^{1}$ Duan (1983).

${ }^{2} \mathrm{MSPE}$ is root-mean-squared error (a measure of the variance between regression-computed and measured values) expressed as a percentage (Rasmussen and others, 2009). 
Table 3. Suspended-sediment concentration, in-stream turbidity, discharge, percent silt/clay (less than 63 micrometers in diameter), and particle-size distribution from discrete samples collected at the Wakarusa River near Richland streamgage (station 06891260) and the Clinton Lake outlet site, 2011-12.

[Samples collected are equal-width interval samples. SSC, suspended-sediment concentration; mg/L, milligrams per liter; FNU, formazin nephelometric units; $\mathrm{ft}^{3} / \mathrm{s}$, cubic feet per second; $\mu \mathrm{m}$, micrometers; $<$, less than; --, not available]

\begin{tabular}{|c|c|c|c|c|c|c|c|c|c|c|}
\hline \multirow{2}{*}{$\begin{array}{c}\text { Sample date } \\
\text { (month/day/ } \\
\text { year) }\end{array}$} & \multirow{2}{*}{$\begin{array}{c}\text { SSC } \\
(\mathrm{mg} / \mathrm{L})\end{array}$} & \multirow{2}{*}{$\begin{array}{c}\text { In-stream } \\
\text { turbidity } \\
\text { (FNU) }\end{array}$} & \multirow{2}{*}{$\begin{array}{l}\text { Discharge } \\
\qquad\left(\mathrm{ft}^{3} / \mathrm{s}\right)\end{array}$} & \multicolumn{7}{|c|}{ Percent of suspended-sediment (by weight) less than specified diameter $(\mu \mathrm{m})$} \\
\hline & & & & $<100$ & $<63$ & $<31$ & $<16$ & $<8$ & $<4$ & $<2$ \\
\hline \multicolumn{11}{|c|}{ Wakarusa River near Richland, Kansas (fig. 1, station number 06891260) } \\
\hline $04 / 26 / 11$ & 293 & 171 & 561 & 100 & 93 & 81 & 64 & 52 & 47 & 43 \\
\hline $04 / 26 / 11$ & 356 & 237 & 657 & 100 & 90 & 78 & 61 & 50 & 45 & 38 \\
\hline $05 / 26 / 11$ & 770 & 555 & 737 & 100 & 98 & 95 & 87 & 76 & 67 & 61 \\
\hline $05 / 26 / 11$ & 546 & 404 & 635 & 100 & 99 & 96 & 90 & 79 & 71 & 58 \\
\hline $03 / 08 / 12$ & 111 & 88 & 20 & -- & 100 & -- & -- & -- & -- & -- \\
\hline $03 / 22 / 12$ & 2,210 & 879 & 1,720 & -- & 94 & -- & -- & -- & -- & -- \\
\hline $03 / 22 / 12$ & 2,260 & 982 & 1,700 & -- & 97 & -- & -- & -- & -- & -- \\
\hline $03 / 22 / 12$ & 2,220 & 1,010 & 1,650 & 100 & 91 & 81 & 65 & 52 & 45 & 36 \\
\hline $04 / 20 / 12$ & 35 & 22 & 24 & -- & 99 & -- & -- & -- & -- & -- \\
\hline \multicolumn{11}{|c|}{ Outlet at Clinton Lake, Kansas (fig. 1, station number 385548095192701) } \\
\hline 03/07/11 & 6 & 5.6 & 529 & -- & -- & -- & -- & -- & -- & -- \\
\hline $04 / 18 / 11$ & 12 & 12.8 & 46 & -- & -- & -- & -- & -- & -- & -- \\
\hline $03 / 08 / 12$ & 14 & 14 & 3.1 & -- & 99 & -- & -- & -- & -- & -- \\
\hline $04 / 16 / 12$ & 26 & 21.8 & 63 & -- & 100 & -- & -- & -- & -- & -- \\
\hline $04 / 17 / 12$ & 21 & 19 & 63 & -- & 98 & -- & -- & -- & -- & -- \\
\hline $05 / 02 / 12$ & 10 & 8.9 & 22 & -- & 98 & -- & -- & -- & -- & -- \\
\hline
\end{tabular}

Clinton Lake was computed to be 44.4 million pounds (lbs). Mean annual suspended-sediment yield for the Clinton Lake Basin was estimated to be $60,500 \mathrm{lbs}$ per square mile per year. Because this study was completed during a drought, the estimated inflow suspended-sediment load and suspendedsediment yield likely are substantially less than what would occur during a period of average or above average precipitation and runoff. The total 2-year outflow SSL from Clinton Lake was computed to be 1.49 million lbs. Sediment trap efficiency for Clinton Lake, computed using only the days for which zero flow was not measured at the Richland and outlet sites, was estimated to be 97 percent. For large reservoirs, a trap efficiency greater than 90 percent is typical (Brune, 1953; Williams and Wolman, 1984; Shotbolt and others, 2005).

The relation between discharge and SSL in the inflow to Clinton Lake was determined by a comparison of total discharge to total SSL for water years 2011 and 2012 at the Richland streamgage (fig. 1). In water year 2011, total discharge was 817 million cubic feet $\left(\mathrm{ft}^{3}\right)$ and total SSL was 14.1 million lbs. In water year 2012, total discharge was 652 million $\mathrm{ft}^{3}$ (20 percent less) and total SSL was 14.5 million lbs (3 percent more). For the 2-year monitoring period at the Richland streamgage, the standardized SSL, computed as the total SSL divided by the total discharge, was 0.02 pound per cubic foot of water or 0.42 ton per acre-foot.

\section{Stormflow Effects on Sediment Transport}

In general, most of the SSL transport for a given year occurs during high-discharge periods (Meade and Parker, 1985; Morris and Fan, 1998; Lee and others, 2008; Juracek, 2011b). This pattern was evident in the present study. At the Richland streamgage for the 2-year study period, 7 storms accounted for about 47 percent of the total discharge and about 91 percent of the total SSL (in 4 percent of the time). The largest stormflow (March 21-27, 2012) during the study period accounted for about 16 percent of the total discharge and about 33 percent of the total SSL (in 0.7 percent of the time).

\section{Sediment Sources for Clinton Lake}

An effective management plan to reduce the sediment loads delivered to Clinton Lake requires an understanding of the type and relative importance of various sediment sources (Collins and Walling, 2004; Walling, 2005). In this discussion, sediment refers to silt and clay because the bottom sediment deposited in the reservoir predominantly was silt and clay (Juracek, 2011a).

The sediment deposited in Clinton Lake mostly originates from four possible sources. Three of the sources are upstream 
from the reservoir and include channel beds, channel banks, and surface soils within the basin (Waters, 1995). Channel-bed degradation for some distance upstream from Clinton Lake is unlikely because the reservoir provides base-level control. The fourth source is the shoreline surrounding the reservoir (Morris and Fan, 1998). Any of these four sources potentially may contribute a substantial amount of sediment to the reservoir.

Atmospheric deposition was assumed to be insignificant.

The relative importance (that is, in terms of the amount of sediment contributed) of the four sediment sources for Clinton Lake is uncertain. Determination of the relative importance of sediment sources may be possible using chemical tracers or other methods. For example, in a study of Perry Lake, Kansas (fig. 1), chemical tracers were used to determine that channel banks were more important than surface soils as sediment sources for the reservoir (Juracek and Ziegler, 2009).

As part of an overall understanding of sediment sources, three considerations are important and worth noting. First, sediment yield can vary substantially throughout a basin and a small percentage of a basin can account for a large percentage of the sediment yield (Morris and Fan, 1998; Russell and others, 2001; Lee and others, 2009). Second, the contribution of sediment from channel erosion tends to become more important with distance downstream in a basin (Knighton, 1998; Lawler and others, 1999; Walling, 2005; Juracek and Ziegler, 2009). Finally, the relative contribution of various sediment sources likely will change with time.

\section{Summary and Conclusions}

A 3-year study by the U.S. Geological Survey, in cooperation with the Kansas Water Office, was begun in 2010 to determine the SSL delivered to Clinton Lake and the amount of suspended sediment retained in the reservoir. Hourly SSC was computed using regression equations developed from SSC and turbidity data collected at an upstream and downstream site. Computed hourly SSC and measured hourly streamflow data were used to compute the inflow and outflow SSLs for October 1, 2010, to September 30, 2012. The results of this study are summarized below:

1. The total 2-year inflow SSL to Clinton Lake was computed to be 44.4 million lbs.

2. The total 2-year outflow SSL from Clinton Lake was computed to be 1.49 million lbs.

3. Sediment trap efficiency for Clinton Lake was estimated to be 97 percent.

4. The mean annual suspended-sediment yield from the Clinton Lake Basin was estimated to be $60,500 \mathrm{lb} / \mathrm{mi}^{2} / \mathrm{yr}$.

5. For Clinton Lake, most of the inflow suspended-sediment load was delivered during short-term, high-discharge periods.
6. Because this study was completed during a drought, the estimated inflow suspended-sediment load and suspendedsediment yield likely are substantially less than what would occur during a period of average or above average precipitation and runoff.

\section{References Cited}

Brune, G.M., 1953, Trap efficiency of reservoirs: Transactions of the American Geophysical Union, v. 34, p. 407-448.

Collins, A.L., and Walling, D.E., 2004, Documenting catchment suspended sediment sources-Problems, approaches and prospects: Progress in Physical Geography, v. 28, p. 159-196.

Duan, Naihua, 1983, Smearing estimate-A nonparametric retransformation method: Journal of the American Statistical Association, v. 78, p. 605-610.

Fenneman, N.M., 1946, Physical divisions of the United States: U.S. Geological Survey special map, scale 1:7,000,000, 1 sheet.

Guy, H.P., 1969, Laboratory theory and methods for sediment analysis: U.S. Geological Survey Techniques of WaterResources Investigations, book 5, chap. C1, 58 p.

Helsel, D.R., and Hirsch, R.M., 1992, Statistical methods in water resources: Amsterdam, Elsevier Science Publishers, $529 \mathrm{p}$.

High Plains Regional Climate Center, 2012, Historical climate

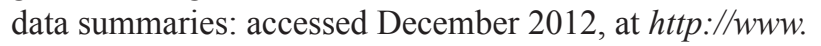
hprcc.unl.edu/.

Jordan, P.R., and Stamer, J.K., eds., 1995, Surface-water-quality assessment of the lower Kansas River Basin, Kansas and Nebraska-Analysis of available data through 1986: U.S. Geological Survey Water-Supply Paper 2352-B, 161 p.

Juracek, K.E., 2011a, Sedimentation and occurrence and trends of selected nutrients, other chemical constituents, and cyanobacteria in bottom sediment, Clinton Lake, northeast Kansas, 1977-2009: U.S. Geological Survey Scientific Investigations Report 2011-5037, 28 p.

Juracek, K.E., 2011b, Suspended-sediment loads, reservoir sediment trap efficiency, and upstream and downstream channel stability for Kanopolis and Tuttle Creek Lakes, Kansas, 2008-10: U.S. Geological Survey Scientific Investigations Report 2011-5187, 35 p.

Juracek, K.E., and Ziegler, A.C., 2009, Estimation of sediment sources using selected chemical tracers in the Perry Lake Basin, Kansas, USA: International Journal of Sediment Research, v. 24, p. 108-125. 
Kansas Applied Remote Sensing Program, 2009, 2005 Kansas land cover patterns, scale 1:50,000: accessed October 2010,

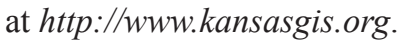

Kansas Biological Survey, 2010, Bathymetric and sediment survey of Clinton Lake reservoir, Douglas County, Kansas: Kansas Biological Survey Applied Science and Technology for Reservoir Assessment Program Report 2009-09, 27 p.

Kansas Water Office, 2012, Clinton Lake, Reservoir information sheet: accessed December 2012, at http://www.kwo.org/ reservoirs/ReservoirFactSheets/Rpt_Clinton_2011.pdf.

Knighton, D., 1998, Fluvial forms and processes-A new perspective: New York, John Wiley and Sons, 383 p.

Lawler, D.M., Grove, J.R., Couperthwaite, J.S., and Leeks, G.J.L., 1999, Downstream change in river bank erosion rates in the Swale-Ouse system, northern England: Hydrological Processes, v. 13, p. 977-992.

Lee, C.J., Rasmussen, P.P., and Ziegler, A.C., 2008, Characterization of suspended-sediment loading to and from John Redmond Reservoir, east-central Kansas, 2007-2008: U.S. Geological Survey Scientific Investigations Report 2008-5123, $25 \mathrm{p}$.

Lee, C.J., Rasmussen, P.P., Ziegler, A.C., and Fuller, C.C., 2009, Transport and sources of suspended sediment in the Mill Creek Watershed, Johnson County, northeast Kansas, 2006-07: U.S. Geological Survey Scientific Investigations Report 2009-5001, 52 p.

Meade, R.H., and Parker, R.S., 1985, Sediment in rivers of the United States: National Water Summary 1984, U.S. Geological Survey Water-Supply Paper 2275, p. 49-60.

Morris, G.L., and Fan, Jiahua, 1998, Reservoir sedimentation handbook: New York, McGraw-Hill [variously paged].

Nolan, K.M., Gray, J.R., and Glysson, G.D., 2005, Introduction to suspended-sediment sampling: U.S. Geological Survey Scientific Investigations Report 2005-5077, CD-ROM.

Owens, P.N., Batalla, R.J., Collins, A.J., Gomez, B., Hicks, D.M., Horowitz, A.J., Kondolf, G.M., Marden, M., Page, M.J., Peacock, D.H., Petticrew, E.L., Salomons, W., and Trustrum, N.A., 2005, Fine-grained sediment in river systems-Environmental significance and management issues: River Research and Applications, v. 21, p. 693-717.

Rasmussen, P.P., and Ziegler, A.C., 2003, Comparison and continuous estimates of fecal coliform and Escherichia coli bacteria in selected Kansas streams, May 1999 through April 2002: U.S. Geological Survey Water-Resources Investigations Report 03-4056, $80 \mathrm{p}$.
Rasmussen, P.P., Gray, J.R., Glysson, G.D., and Ziegler, A.C., 2009, Guidelines and procedures for computing time-series suspended-sediment concentrations and loads from instream turbidity-sensor and streamflow data: U.S. Geological Survey Techniques and Methods, book 3, chap. C4, $53 \mathrm{p}$.

Rasmussen, T.J., Ziegler, A.C., and Rasmussen, P.P., 2005, Estimation of constituent concentrations, densities, loads, and yields in lower Kansas River, northeast Kansas, using regression models and continuous water-quality monitoring, January 2000 through December 2003: U.S. Geological Survey Scientific Investigations Report 2005-5165, 117 p.

Russell, M.A., Walling, D.E., and Hodgkinson, R.A., 2001, Suspended sediment sources in two small lowland agricultural catchments in the UK: Journal of Hydrology, v. 252, p. $1-24$.

Schoewe, W.H., 1949, The geography of Kansas: Transactions Kansas Academy of Science, v. 52, p. 261-333.

Shotbolt, L.A., Thomas, A.D., and Hutchinson, S.M., 2005, The use of reservoir sediments as environmental archives of catchment inputs and atmospheric pollution: Progress in Physical Geography, v. 29, p. 337-361.

Turnipseed, D.P., and Sauer, V.B., 2010, Discharge measurements at gaging stations: U.S. Geological Survey Techniques and Methods, book 3, chap. A8, 87 p.

U.S. Army Corps of Engineers, 1979, Lower Kansas River Basin lake regulation manual, volume 4, Clinton Lake: Kansas City, Missouri, U.S. Army Corps of Engineers, Kansas City District [variously paged].

U.S. Department of Agriculture, Soil Conservation Service, 1970, Soil survey of Shawnee County, Kansas: U.S. Department of Agriculture, Soil Conservation Service, 77 p.

U.S. Department of Agriculture, Soil Conservation Service, 1977, Soil survey of Douglas County, Kansas: U.S. Department of Agriculture, Soil Conservation Service, $73 \mathrm{p}$.

U.S. Department of Agriculture, Soil Conservation Service, 1985, Soil survey of Osage County, Kansas: U.S. Department of Agriculture, Soil Conservation Service, 100 p.

U.S. Department of Agriculture, Soil Conservation Service, 1991, Soil survey of Wabaunsee County, Kansas: U.S. Department of Agriculture, Soil Conservation Service, $132 \mathrm{p}$.

U.S. Geological Survey, 2013, National Water Information System (NWISWeb): accessed February 2013, at http:// waterdata.usgs.gov/ks/nwis/sw/. 
Wagner, R.J., Boulger, R.W., Jr., Oblinger, C.J., and Smith, B.A., 2006, Guidelines and standard procedures for continuous water-quality monitors-Station operation, record computation, and data reporting: U.S. Geological Survey Techniques and Methods 1-D3, 51 p. plus 8 attachments, accessed November 2008, at http://pubs.water.usgs.gov/ tm $1 d 3$.

Walling, D.E., 2005, Tracing suspended sediment sources in catchments and river systems: Science of the Total Environment, v. 344, p. 159-184.
Waters, T.F., 1995, Sediments in streams-Sources, biological effects and control: Bethesda, Maryland, American Fisheries Society, $251 \mathrm{p}$.

Williams, G.P., and Wolman, M.G., 1984, Downstream effects of dams on alluvial rivers: U.S. Geological Survey Professional Paper 1286, 83 p.

YSI, 2007, YSI 6136 turbidity sensor: accessed October 4, 2010, at http://www.ysi.com/media/pdfs/E56-6136Turbidity-Sensor.pdf. 
Publishing support provided by:

Rolla Publishing Service Center

For additional information concerning this publication, contact: Director, USGS Kansas Water Science Center 4821 Quail Crest Place

Lawrence, KS 66049

(785) 842-9909

Or visit the Kansas Water Science Center Web site at: http://ks.water.usgs.gov 


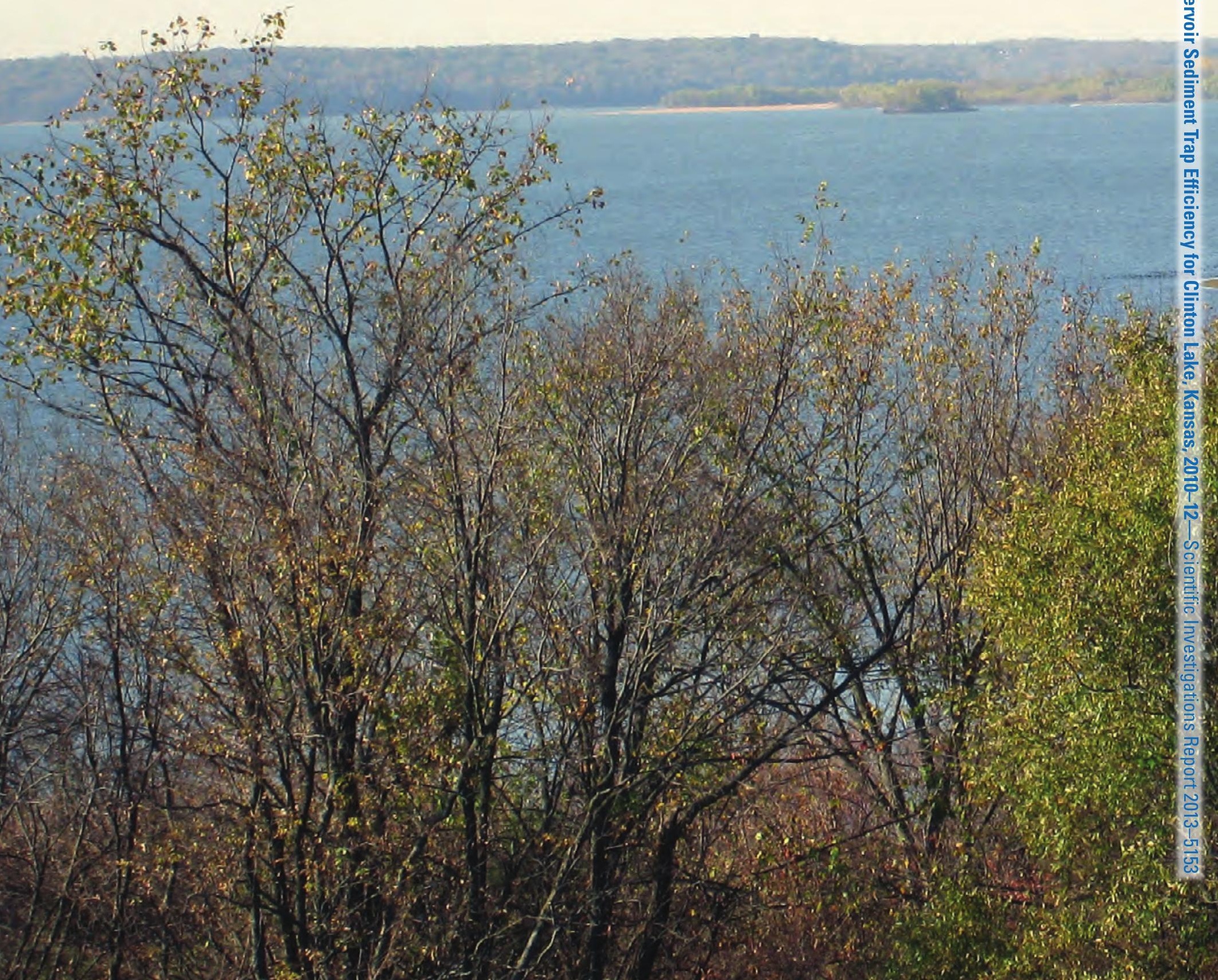

